\title{
Antimalarial Activity of Ethanol Extract of Kelakai Leaves (Stenochlaena palustris) to Parasitemia and Splenomegaly in BALB/c Mice Infected with Plasmodium berghei ANKA
}

\author{
Laily Nur Azizah ${ }^{1}$, Puspa Wardhani ${ }^{2} \mathbb{i}$, Heny Arwati ${ }^{3}$ iif
}

${ }^{1}$ Faculty of Medicine, Universitas Airlangga, Surabaya, Indonesia.

2Department of Clinical Pathology, Faculty of Medicine, Universitas Airlangga/Dr. Soetomo General Hospital, Surabaya, Indonesia.

${ }^{3}$ Department of Parasitology, Universitas Airlangga, Surabaya, Indonesia.

A B S TR A C T

Introduction: Malaria is one of global health problems. Splenomegaly is one of malaria symptoms. Antimalarial drug resistance had been reported. Alternative treatment is by using traditional medicinal plants such as kelakai (Stenochlaena palustris). Kelakai contains alkaloid and flavonoid which had been reported to have antimalarial activity. The aim of this study was to discover antimalarial activity of ethanol extract of kelakai leaves to parasitemia and splenomegaly of Plasmodium berghei ANKA in infected BALB/c mice.

Methods: This study was based on a modified Peter test using BALB/c mice infected with $P$. berghei ANKA treated with ethanol extract of kelakai leaves, with chloroquine diphosphate as a positive control. The negative control was $P$. berghei ANKA infected mice without any additional treatment. Administration of ethanol extract of kelakai leaves was performed for 4 days with a serial doses of 100,10 , and $1 \mathrm{mg} / \mathrm{kg}$ body weight. The positive control was given chloroquine diphosphate $20 \mathrm{mg} / \mathrm{kg}$ body weight. Parasitemia was observed daily prior to the calculation of the percentage of parasite growth and parasite growth inhibition. At the end of the test, the mice were sacrificed and spleens were isolated to measure their sizes. Probit analysis was performed to obtain $\mathrm{ED}_{50}$ to find the effect of extract in parasite killing by $50 \%$. Spearman test was performed to analyze the correlation of doses of extract and splenomegaly.

Results: Parasitemia growth inhibition was directly proportional to the dose. Higher parasitemia inhibition was obtained at higher doses and vice versa. Result of probit analysis showed an ED50 was $77.05 \mathrm{mg} / \mathrm{kg}$ body weight. Statistical analysis resulted in insignificant correlation between doses and splenomegaly $p=1.0$ (significancy < 0.05).

Conclusion: Ethanol extract of kelakai leaves possessed good antimalarial activity and there was no correlation between extract doses and splenomegaly in Plasmodium berghei ANKA-infected mice.

\section{*Correspondence: puspa_pk@yahoo.co.id}

JUXTA: Jurnal IImiah Mahasiswa Kedokteran Universitas Airlangga

p-ISSN: 1907-3623; e-ISSN: 2684-9453

DOI: 10.20473/juxta.V13I12022.1-5

Open access under Creative Commons Attribution-ShareAlike 4.0 International License (CC-BY-SA)
ARTICLEINFO

Article history:

Received 19 October 2021

Received in revised form 16

December 2021

Accepted 20 December 2021

Available online 5 January 2022

Keywords:

Antimalarial activity,

Kelakai,

Malaria,

Splenomegaly. 


\section{Introduction}

Malaria is one of global health problems which occurs in tropical and subtropical countries. Anopheles mosquito as a malaria vector can grow and multiply. ${ }^{1}$ Splenomegaly is caused by phagocytosis of infected erythrocytes and hemozoin by splenocytes. ${ }^{2}$ Splenomegaly is usually found in human chronic malaria infection. ${ }^{3}$

In 2017, 219 million malaria cases were found and 435,000 people died. Malaria prevalence in Africa was $92 \%$, in Southeast Asia was $5 \%$, and in Eastern Mediterania area was $2 \%{ }^{4}$ The incidence of malaria in Indonesia, according to Baseline Health Research (Riskesdas) 2013 , was $0.35 \%$ or 3.5 of 1,000 population. It was found that 3 provinces with the highest incidence were Papua (6.1\%), West Papua (4.5\%), and East Nusa Tenggara $(2.6 \%){ }^{5}$

In Indonesia, parasite resistance against antimalarial drug such as Chloroquine and Sulfadoksin-Pirimethamin was reported. The first resistance to Chloroquine occurred in 1973, which was found in Plasmodium falciparum parasites. In 1990, there was resistance to $P$. falciparum parasites against Chloroquine from all provinces in Indonesia. In addition, resistance was also found in Plasmodium against Sulfadoksin-Pirimethamin (SP) in several regions in Indonesia. ${ }^{6}$ Alternative of malaria treatment is needed, one of them is using medicinal plants. One of them is Kelakai (Stenochlaena palustris). Kelakai is a plant that grows wildly in South Kalimantan. This plant is easy to be obtained because it can be found in traditional markets in South Kalimantan. Dayak Kenyah tribe use it to treat anemia, relieve fever, and skin aches. Kelakai leaves extract contain flavonoids, alkaloids and steroids. ${ }^{7}$ Alkaloids and flavonoids have antimalarial effects. The effect of alkaloid is inhibit heme polymerase and causes heme deposit which is toxic to Plasmodium. ${ }^{8}$ Flavonoid is able to inhibit the biosynthesis of fatty acids (FAS II) in parasites, inhibit the entry of L-glutamine and myoinositol into erythrocytes. ${ }^{9}$

Mice which are often use as a model for immunology is BALB/c mice. ${ }^{10}$ In malaria studies, mice are used for infection with $P$. berghei infection which is able to reach high parasitemia. ${ }^{11}$ Plasmodium berghei ANKA is one of the parasites that causes malaria in rodents, including mice. ${ }^{12} P$. berghei ANKA can be used as a model of human malaria study in mice due to its similar characteristics to $P$. falciparum. Virulence of $P$. berghei ANKA is similar to $P$. falciparum which infects all ages of erythrocytes and causes pathological abnormalities in organs. ${ }^{13}$

Ethanol is a polar non-toxic solvent and has a relatively low price in the market. These are the reasons for using ethanol as a solvent to prepare the extract of kelakai leaves. ${ }^{14}$ In addition, compounds in plants when extracted using ethanol solvents will be more stable because ethanol solvents have antimicrobial effect. Ethanol solvents can dissolve polar and non-polar compounds in almost all organic compounds from plants and can open the cell wall of the plant and draw almost all the compounds from the extracted plant out of the cell. ${ }^{15,16}$

Based on the relation between parasitemia and splenomegaly, the effect of extract doses on parasitemia could also be studied in relation to splenomegaly. The aim of this study was to discover antimalarial activity of ethanol extract of kelakai leaves against parasitemia and splenomegaly of Plasmodium berghei ANKA in infected $\mathrm{BALB} / \mathrm{c}$ mice.

\section{Methods}

\section{Research Design}

This was a laboratory experimental study. The independent variables in this study were the dosage of ethanol extract of the kelakai leaves 100,10 , and $1 \mathrm{mg} / \mathrm{kg}$ body weight. The dependent variable in this study were the percentage of parasitemia and the mean of splenomegaly of the mice which were given ethanol extract of kelakai leaves. This study was performed from March to June 2018.

\section{Research Material}

Ethanol extract of kelakai leaves were obtained from Laboratory of Parasitology, Faculty of Medicine, Universitas Airlangga, Surabaya. The ethanol extract of Kelakai leaves was made with $96 \%$ ethanol as solvent.

\section{Parasites and Animal}

Plasmodium berghei in this study was ANKA strain obtained from the Laboratory of Parasitology, Faculty of Medicine, Universitas Airlangga, Surabaya. The mice used in this study were 8 weeks BALB / c male mice with 20-25 grams body weight obtained from Experimental Animal Unit of Department of Biochemistry, Faculty of Medicine, Universitas Airlangga, Surabaya. 25 mice were divided into 5 groups. They were treated with the doses of $1 ; 10 ; 100$ $\mathrm{mg} / \mathrm{kg}$ body weight, positive controls were given $20 \mathrm{mg} /$ $\mathrm{kg}$ body weight chloroquine diphosphate, and negative controls were only infected with Plasmodium berghei ANKA without any additional treatment. Every mice was injected with $P$. berghei ANKA $1 \times 10^{6}$ of $P$. berghei ANKA infected erythrocytes or $200 \mu \mathrm{l}$ infected blood / mice intraperitoneally.

\section{Antimalarial Activity Test}

The test was based on a modification of Peter test. ${ }^{17}$ Administration of ethanol extract of kelakai leaves was performed for 4 consecutive days. Parasitemia was observed daily of blood smears stained with $10 \%$ Giemsa. It was calculated per 1000 erythrocytes. Based on parasitemia, the percentage of parasite growth and the percentage of parasite growth inihibition were calculated. The percentage of parasite growth and the percentage of parasite growth inhibition were calculated using the following formula: ${ }^{18}$ 


$$
\% \text { growth }=\frac{\sum\left[D x-D_{x-1}\right]}{n-1}
$$

Where $\left(D_{x}-D_{x-1}\right): \%$ parasitemia on $x$-day minus \% parasitemia on day before $\mathrm{n}$ : number of observation day

$$
\% \text { inhibition }=100 \%-\left(\left|\frac{X_{e}}{X_{k}}\right| \times 100 \%\right)
$$

Where Xe: percentage of the average parasite growth in the group given the test solution, Xk: percentage of the average parasite growth in the negative control.

Based on the data of the percentage of growth inhibition, the probit analysis was performed to obtain $E_{50}$ which indicated concentration of the extract that killed parasite by $50 \%$.

Observation of splenomegaly was perfomed at the end of the test. The mice were sacrificed and spleens were removed to measure the length and width of the spleen and then calculated the wide of spleen. Correlation of concentration of the extract and size of spleen was analysed by using Spearman test.

\section{Ethical Clearance}

This study was approved by Health Research Ethics Committee, Faculty of Medicine, Universitas Airlangga, Surabaya.

\section{Results}

\section{Parasitemia}

Observations of blood smear from BALB / c mice infected with $P$. berghei ANKA with a light microscope at 1000 times magnification resulted in percentage of parasitemia as shown in Table 1.

Table 1 . The average daily percentages of parasitemia in $P$. berghei ANKA infected BALB/c mice

\begin{tabular}{ccccccc}
\hline Treatment & $\begin{array}{c}\text { Doses } \\
\text { (mg/kg } \\
\text { body } \\
\text { weight) }\end{array}$ & D0 & D1 & D2 & D3 & D4 \\
\hline EE of $\mathrm{KL}^{*}$ & 100 & 17.35 & 20.93 & 26.79 & 31.18 & 26.40 \\
EE of $\mathrm{KL}^{*}$ & 10 & 7.42 & 9.87 & 13.23 & 16.09 & 17.88 \\
EE of $\mathrm{KL}^{*}$ & 1 & 8.5 & 10.86 & 13.63 & 16.44 & 20.63 \\
$\begin{array}{c}\text { Chloroquine } \\
\text { diphosphate }\end{array}$ & 20 & 14.09 & 5.57 & 3.16 & 3.65 & 0.78 \\
None & - & 11.34 & 15.91 & 20.43 & 26.61 & 29.69 \\
\hline \multicolumn{7}{c}{} \\
& ${ }^{*}$ EE of KL: Ethanol Extract of Kelakai Leaves
\end{tabular}

Based on the percentage of parasitemia, the percentage of parasite growth and parasite growth inhibition were presented in Table 2.

Table 2. Percentage of growth and growth inhibition of $P$. berghei ANKA after treatments

\begin{tabular}{cccc}
\hline Treatment & $\begin{array}{c}\text { Doses (mg/ } \\
\text { kg body } \\
\text { weight) }\end{array}$ & $\begin{array}{c}\text { Growth } \\
(\%)\end{array}$ & $\begin{array}{c}\text { Inhibition } \\
(\%)\end{array}$ \\
\hline
\end{tabular}

\begin{tabular}{cccc}
\hline EE of $\mathrm{KL}^{*}$ & 100 & 2.26 & 50.63 \\
EE of $\mathrm{KL}^{*}$ & 10 & 2.61 & 42.99 \\
$\mathrm{EE}$ of $\mathrm{KL}^{*}$ & 1 & 3.03 & 33.90 \\
$\begin{array}{c}\text { Chloroquine } \\
\text { diphosphate } \\
\text { None }\end{array}$ & 20 & - & 100 \\
\hline \multicolumn{4}{c}{ *EE of KL: Ethanol Extract of Kelakai Leaves }
\end{tabular}

The results showed the percentage of parasite growth was inversely proportional to the percentage of parasite growth inhibition. The higher percentage of parasite growth, the lower percentage of parasite growth inhibition. The percentage of parasite growth inhibition was directly proportional to the doses. The percentages of parasite growth in treated mice compared with negative control was lower, indicating that the extract affected parasite growth, while the percentage of parasite growth inhibition in treated mice compared with positive control was lower because Chloroquine is a potent antimalarial and $P$. berghei ANKA is Chloroquine sensitive.

\section{Effective Dose $50\left(E D_{50}\right)$ of Ethanol Extract of Kelakai Leaves}

Probit analysis of data on $P$. berghei ANKA growth inhibition and doses of ethanol extract of kelakai leaves obtained ED50 as much as 77.05 mg / kg body weight.

\section{Correlation of Splenomegaly and Doses of Ethanol Extract of Kelakai Leaves}

Splenomegaly was observed in the mice treated with ethanol extract of kelakai leaves, Chloroquine, and negative control, and then compared to normal mice. The spleens of treated mice were more blackish and larger in size, whereas in normal mice the spleen was fresh red and smaller with the spleen sizes of $0.72-1.25 \mathrm{~cm}^{2}$.

Table 3. The average spleen size in $P$. berghei ANKA infected BALB/c mice after treatments

\begin{tabular}{ccc}
\hline Treatment & $\begin{array}{c}\text { Doses }(\mathbf{m g} / \mathbf{~ k g} \\
\text { body weight) }\end{array}$ & $\begin{array}{c}\text { Spleen sizes } \\
\left(\mathbf{c m}^{2}\right)\end{array}$ \\
\hline EE of $\mathrm{KL}^{*}$ & 100 & 2.04 \\
EE of $\mathrm{KL}^{*}$ & 10 & 1.50 \\
$\mathrm{EE}$ of $\mathrm{KL}^{*}$ & 1 & 2.11 \\
$\begin{array}{c}\text { Chloroquine } \\
\text { diphosphate } \\
\text { None }\end{array}$ & 20 & 1.77 \\
\hline \multicolumn{2}{c}{${ }^{*}$ EE of KL: Ethanol Extract of Kelakai Leaves }
\end{tabular}

Spearman correlation test showed that there was insignificant correlation between splenomegaly and extract dose with $p=1.0$ (significance $<0.05$ ).

\section{Discussion}

The results of this study showed different fluctuations in parasitemia in the treatment group from day 0 to day 4 . Based on the results, parasitemia in the test group was 
lower than in negative control, indicating that the ethanol extract of kelakai leaves possessed antimalarial activity. Probit analysis showed ED50 was $77.05 \mathrm{mg} / \mathrm{kg}$ body weight and was considered as good antimalarial activity. Herintsoa classification showed that an extract which has antimalarial activity is considered very good if $E_{50}<10 \mathrm{mg}$ / kg body weight; considered good if ED $\mathrm{ED}_{50} 10-100 \mathrm{mg} / \mathrm{kg}$ body weight; rated moderate if ED $50100-1000 \mathrm{mg} / \mathrm{kg}$ body weight; and considered not having antimalarial activity if $E_{50}>1000 \mathrm{mg} / \mathrm{kg}$ body weight. ${ }^{19}$

In vivo tests of antimalarial activity of ethanol extract of kelakai leaves in BALB / c mice were based on bioactive substances in kelakai leaves which have antimalarial effect. Bioactive substances in kelakai leaves are flavonoids, steroids, and alkaloids. Alkaloids are the most dominant ingredient. ${ }^{7}$ Alkaloids have antipyretic, antiinflammatory, and antimalarial effects. ${ }^{20,21}$ Alkaloids inhibit heme polymerase and cause heme deposit in food vacuole which is toxic to Plasmodium. ${ }^{8}$ The content of flavonoids in kelakai leaves are $14.5 \mu \mathrm{g} / \mathrm{ml}^{22}$ Flavonoids have antiinflammatory and antimalarial effect. Flavonoids inhibit parasitic fatty acid biosynthesis (FAS II), influx L-glutamine and myoinositol into infected erythrocytes, and disrupt the growth of Plasmodium. ${ }^{9}$ In addition, kelakai leaves also contain phenolic and anthraquinone. ${ }^{23}$

Malaria infection usually has several symptoms, one of which is splenomegaly as a clinical manifestation of high parasitemia and immune reaction against infection. ${ }^{13}$ High parasitemia increases phagocytosis of infected erythrocytes and hemozoin in the red pulp area and hosts immune reaction in white pulp area which causes enlargement of spleen. ${ }^{2,24}$ In splenomegaly, spleen also changes color from fresh red to blackish brown. The color change is due to hemozoin and hemosiderin accumulation in the spleen. Hemozoin is a waste product from the digestion of hemoglobin by malaria which has black or brown color. Hemosiderin is the substance produced by the breakdown of brown hemoglobin. ${ }^{25}$

In this study, it was found that the ethanol extract of kelakai leaves had antimalarial activity against parasitemia in the blood, but had no effect on splenomegaly. It can be seen in each group of mice which were given extracts with doses of 1,10, 100 parasitic growth inhibition and positive control decreasing parasitemia, whereas the size of the spleen was enlarged in groups of mice which given extracts with doses of $1,10,100$ positive control and negative control. Chloroquine which was given to positive controls was effective in reducing parasitemia, but did not inhibit splenomegaly. It happened because chloroquine only works against parasites in the blood, but it is not effective in tissues. ${ }^{2}$ Thus, the mechanism of ethanol extract of kelakai leaves against $P$. berghei ANKA in mice was similar with chloroquine.

\section{Conclusion}

Ethanol extract of kelakai leaves possessed good antimalarial activity with an ED 50 of $77.05 \mathrm{mg} / \mathrm{kg}$ body weight, inhibiting parasitemia growth in a similar mechanism to chloroquine, and there was no correlation between extract doses and splenomegaly in Plasmodium berghei ANKA-infected mice.

\section{CONFLICT OF INTEREST}

The author stated there is no conflict of interest in this study.

\section{REFERENCES}

1.CDC. Where Malaria Occurs. 2017, https://www.cdc.gov/malaria/about/distribution.htm (2017).

2. del Portillo HA, Ferrer M, Brugat T, et al. The role of the spleen in malaria. Cell Microbiol 2012; 14: 343355.

3. CDC. About Malaria. 2015.

4. WHO. World malaria report 2018. 2018.

5. Kemenkes R. Profil Kesehatan RI 2015. 2015. Epub ahead of print 2015. DOI: 10.1111/evo.12990.

6. Depkes RI. Epidemiologi Malaria di Indonesia eds. Buletin Jendela Data Dan Informasi Kesehatan Epidemiologi Malaria Di Indonesia. Kementrian Kesehat RI 2011; 1-40.

7. Maharani D, Haidah S, Haiyinah. Studi Potensi Kalakai (Stenochlaena palustris (BURM.F) BEDD), SEBAGAI PANGAN FUNGSIONAL. Pimnas 2006, http://studentresearch.umm.ac.id/index.php/pimnas/article/view /255/516\# (2006).

8. Louisa $M$, In Gunawan $S$, Setiabudy $R$, et al. Farmakologi dan Terapan. Jakarta: FK UI, 2016, p. 574.

9. Ntie-Kang $F$, Onguéné PA, Lifongo LL, et al. The potential of anti-malarial compounds derived from African medicinal plants, part II: A pharmacological evaluation of non-alkaloids and non-terpenoids. Malar J; 13. Epub ahead of print 2014. DOI: 10.1186/1475-2875-13-81.

10.Johnson M. Mice and Rats. Labome, https://www.labome.com/method/LaboratoryMice-and-Rats.html\#ref103 (2012).

11.Festing $M$. Inbred Strains: BALB, http://www.informatics.jax.org/inbred_strains/mou se/docs/BALB.shtml (1998, accessed 25 October 2018).

12. McNally J. Erythrocyte Invasion by the Rodent Malaria. Dublin City University, 1994.

13. Nurhayati S. Propagasi Plasmodium berghei Iradias Gamma Laju Dosis Tinggi pada Mencit (Mus musculus). Semin Nas Keselam Kesehat dan Lingkung VII 2011; 88-96.

14. Prajnalaga F, Susilowati E. Perbandingan Ekstrak Etanol dan Metanol Daun Gaharu (Aquilaria malaccensis) Terhadap Aktivitas Antiradikan Bebas Dengan Metode DPPH. 2014; 1-9.

15. Nurmilatina. Analisis Komposisi Kimia Daun Kelakai (Stenochlaena palustris Bedd.) dengan Berbagai Pelarut menggunakan GCMS. J Ris Ind Has Hutan 2017; 9: 9-16

16. Harahap R, Batubara R, Surjanto. Uji Antioksidan Daun Muda dan Daun Tua Gaharu (Aquilaria malaccensis Lamk) berdasarkan perbedaan tempat Tumbuh Pohon. Peronema For Sci J 2015; 4: 72-87.

17. Phillipson J. Assays for Antimalarial and Amoebicidal Activities. Methods Plant Biochem 1991; 6: 135- 
152.

18. Sari S, Hafid AF, Widyawaruyanti ATY. Efek Pemberian Dosis Berulang dan Dosis Tunggal Ekstrak Kulit Batang Cempedak ( Artocarpus Champeden Spreng .) Pada Mencit Terinfeksi Plasmodium Berghei ( Antimalarial Activity of Multiple Dose and Single Dose Administration of Artocarpus Champeden Spreng. J IImu Kefarmasian Indones 2015; 13: 23-28.

19. Herintsoa R, Baholy RR, Andriantiaray R. Screening of Plant Extracts for Searching Antiplasmodial Activity. 11th NAPRECA Symp B Proc 2005; 136144.

20.Suhartono E, Bakhriansyah M, ... Efek Ekstrak Stenochlaena palustris terhadap jumlah circulating endothelial cells Marmota calligata setelah didemamkan. Maj Farm Indones 2010; 21: 166170.

21. Muti'ah R. Penyakit Malaria Dan Mekanisme Kerja
Obat-Obat Antimalaria. Alchemy 2013; 2: 80-91.

22. Suhartono E, Viani E, Rahmadhan MA, et al. Total flavonoid and Antioxidant Activity of Some Selected Medicinal Plants in South Kalimantan of Indonesian. APCBEE Procedia 2012; 4: 235-239.

23. Cahaya N, Aulia R. Efek Daun Kelakai (Stenochlaena palustris) terhadap Jumlah Eritrosit, Bentuk Eritrosit dan Kadar Hemoglobin ( $\mathrm{Hb})$ pada Tikus Putih (Rattus norvegicus) Anemia. Semin Nas.

24. Triajayanti A, Oktarlina RZ. Peran Antioksidan pada Buah Delima dan Buah Merah ( Pandanus conoideus ) terhadap Splenomegali pada Penderita Malaria. Medula 2017; 7: 94-100.

25. Soniran OT, Idowu OA, Ajayi OL, et al. Comparative study on the effects of chloroquine and artesunate on histopathological damages caused by Plasmodium berghei in four vital organs of infected albino mice. Malar Res Treat; 2012. Epub ahead of print 2012. DOI: 10.1155/2012/960758. 